\title{
Macromineral enrichment of white bread reduces postprandial glycaemia without altering sensory properties: a crossover study
}

Rania El Khoury, ${ }^{1}$ Noor El Solh, ${ }^{1}$ Ammar Olabi, ${ }^{1}$ Imad Toufeili, ${ }^{1}$ Sani Hlais ${ }^{1}$ and Omar Obeid ${ }^{1}$

${ }^{1}$ Department of Nutrition and Food Science, Faculty of Agricultural and Food Sciences, American University of Beirut, Beirut, Lebanon (Correspondence to: O. Obeid: omar.obeid@aub.edu.lb).

\begin{abstract}
Background: Metabolism of refined carbohydrates, which are associated with detrimental health effects, is known to be affected by macrominerals including $\mathrm{P}, \mathrm{Mg}$ and $\mathrm{K}$.

Aims: To assess the impact of their addition to flour on the sensory properties of white pita bread and postprandial glycaemia of healthy individuals.

Methods: The study was conducted at the American University of Beirut (between February and October 2014). Plain, restored and fortified wheat flour, with macrominerals were used to prepare 3 types of bread: white pita bread (WP), restored white pita bread (WP-R) (premilling levels) and fortified white pita bread (WP-F) (double the premilling levels). Sensory characteristics of bread were assessed and postprandial glycaemia was determined using a single-blinded crossover design whereby participants consumed 1 of the 3 different types of pita bread in random order.

Results: No significant difference $(P>0.05)$ between the different types of bread was detected using the triangle and acceptability tests, except for texture $(P<0.05)$. Macromineral enrichment of bread (WP-R and WP-F) significantly reduced postprandial glucose $(P=0.013)$ and triglyceride $(P=0.001)$ levels.

Conclusions: Macromineral enrichment of refined carbohydrates may have a promising role in lowering postprandial glucose and triglycerides, and thus decrease their negative health consequences..

Keywords: sensory properties, glucose, triglyceride, white bread, macromineral enrichment

Citation: El Khoury R; El Solh N; Olabi A; Toufeili I; Hlais S; Obeid O. Macromineral enrichment of white bread reduces postprandial glycaemia without altering sensory properties: a crossover study. East Mediterr Health J. 2020;16(11):1388-1395. https://doi.org/10.26719/2020.26.11.1388

Received: 16/05/18; accepted: 26/02/19

Copyright ( World Health Organization (WHO) 2020. Open Access. Some rights reserved. This work is available under the CC BY-NC-SA 3.0 IGO license (https://creativecommons.org/licenses/by-nc-sa/3.o/igo).
\end{abstract}

\section{Introduction}

Over the past few decades, there have gradual but significant changes in eating behaviour worldwide in light of nutritional transition from traditional diets rich in complex carbohydrates to diets high in simple carbohydrates (1). These changes were associated with an increase in the prevalence of chronic diseases and accordingly, the recent dietary guidelines in the United States of America (2) strongly emphasize the importance of reducing simple carbohydrates. Fibre, vitamin and mineral content of flour is drastically reduced by conventional milling and grain refinement processes. Macrominerals including P, $\mathrm{Mg}$ and $\mathrm{K}$, are reduced by about $69 \%, 74 \%$ and $84 \%$, respectively (3), and are known to improve postprandial glucose and insulin metabolism $(4,5)$. P plays an essential role in carbohydrate metabolism via phosphorylation of glucose to glucose-6-phosphate; an essential step for glucose clearance and trapping into cells (6). The need for $\mathrm{P}$ is highest during the postprandial period, as indicated by its reduced level after glucose ingestion and by the improvement in insulin sensitivity following its addition (7). Mg mediates glucose transport mechanisms into the cell membranes through its effect on insulin signalling via tyrosine kinase activity, phosphorylase B kinase activity and glucose transporter protein activity $(8,9)$. $\mathrm{K}$ in its turn acts as a cofactor for several enzymes involved in carbohydrate phosphorylation and oxidation, such as protein kinases and phosphatases. $\mathrm{K}$ is also known to affect glucose tolerance (5). Thus, low availability of the above-mentioned macrominerals would be expected to delay postprandial cellular uptake of glucose, impair phosphorylation, and eventually hinder carbohydrate metabolism and energy production (10). These conditions would ultimately favour the onset and development of the different components of metabolic syndrome, especially impaired glucose tolerance and diabetes (11). In this same context, diminished insulin sensitivity is known to promote hypertriglyceridaemia (12); therefore, serum triglyceride (TG) levels are expected to increase in a setting of low mineral availability.

Refined white flour has received extensive worldwide acceptance, since it is used to produce baked goods that are more palatable, softer in texture and have extended freshness. White pita bread is heavily consumed in the Middle East and increasingly in Europe and North America. Therefore, the objective of this work was to assess the impact of $\mathrm{P}, \mathrm{Mg}$ and $\mathrm{K}$ enrichment on sensory properties and postprandial glycaemia of white pita bread. 


\section{Methods}

\section{Study design}

This study was conducted between February and October 2014, according to the Declaration of Helsinki and all procedures involving human subjects were approved by the Institutional Review Board at the American University of Beirut (approval no. NUToo19). Written informed consent was obtained from all participants. The clinical trial was registered with Clinical Trial.gov, NCT02598986.

Wheat flour $(80 \%$ extraction; Bakalian Flour Mills, Beirut, Lebanon) was used and 2 levels of mineral supplementation were made. Restoration: minerals were added to white flour so that each kilogram contained 3.6 $\mathrm{g} \mathrm{MgCO}_{3}$ (G\&G Vitamins, East Grinstead, UK) and $12.5 \mathrm{~g}$ $\mathrm{KH}_{2} \mathrm{PO}_{4}$ (Dyets, Bethlehem, PA, United State of America). Fortification: minerals were added to white flour to almost double the original levels, so that each kilogram of white flour contained $7.2 \mathrm{~g} \mathrm{MgCO}_{3}$ and $25 \mathrm{~g} \mathrm{KH}_{2} \mathrm{PO}_{4}$. The amounts of added $\mathrm{P}$ and $\mathrm{Mg}$ were considered safe since both were lower than the tolerable upper limits set at $4 \mathrm{~g} /$ day and $350 \mathrm{mg} /$ day for $\mathrm{P}$ and $\mathrm{Mg}$, respectively (13). After supplementation, different types of white pita bread were made and used for the different tests.

\section{White pita bread making}

Bread samples were prepared as previously described (14). Upon termination of the bread making process, 3 samples from each type of bread [white pita bread (WP), white pita bread-restored (WP-R) and white pita bread-fortified (WP-F)] were analysed for their mineral content by inductively coupled plasma mass spectrometry (ICP-MS) using the standard method EPA $200-7 / 8$ (15). P, Mg and K contents of WP-R were $84 \%, 200 \%$ and $60 \%$ higher than those of WP, respectively (Table 1). P, Mg and $\mathrm{K}$ contents of WP-F were $260 \%, 410 \%$ and $230 \%$ higher than those of WP, respectively. P, Mg and K contents of WP-F were almost double those of the WP-R.

\section{Experiment 1: difference and acceptability sensory tests}

Twenty-four healthy untrained male volunteers participated in a difference/discrimination test. Two triangular tests were conducted to compare WP versus WP-R or WP-F. Panellists were asked to indicate the odd sample in each set and to rinse their mouths before each sample. A consumer acceptability test was conducted with 60 healthy randomly recruited panellists ( 29 women and 31 men, mean age 22 years, range $19-29$ years) from the
American University of Beirut as described previously (16). The 3 samples used in different tests were assessed. Ten grams of each type of white pita bread were prepared 2 hours prior to serving them and were stored in the refrigerator $\left(4^{\circ} \mathrm{C}\right)$. Panellists rated overall acceptability, appearance, colour, odour, flavour and texture on a 9-point hedonic scale (17). Panellists were instructed to rinse their mouths before each sample. The order of the samples within each set was randomized among the panellists in both tests.

\section{Experiment 2: determination of postprandial glucose and triglyceride}

Independently from the first experiment, 11 healthy male volunteers were recruited and asked to maintain their regular dietary habits and physical activity during the entire study course, and to avoid alcohol consumption and unusual strenuous exercise 24 hours prior to each experimental session. Volunteers were aged 18-30 years (mean 24.5 years) with body mass index between 18.5 and $29.9 \mathrm{~kg} / \mathrm{m}^{2}$, without significant medical or chronic diseases, with no regular use of medication that affected body weight, and without weight loss of $\geq 3 \%$ in the preceding 3 months.

A single-blinded, randomized crossover study was conducted. Each participant consumed 1 of the 3 different types of pita bread on each of 3 visits. The order of meals was assigned randomly and the visits were separated by a minimum washout period of 10 days. In each session, overnight fasted participants were asked to ingest $90 \mathrm{~g}$ (containing $50 \mathrm{~g}$ carbohydrate) white pita bread within 1015 minutes and subsequently drink $200 \mathrm{ml}$ water. Blood samples were collected at baseline (before ingestion) and at 15, 30, 45, 60, 90 and 120 minutes after ingestion. Blood samples were centrifuged for 15 minutes at $4^{\circ} \mathrm{C}$ at $2500 \mathrm{~g}$ and serum was stored in aliquots at $-80^{\circ} \mathrm{C}$ until analysis. Serum glucose, TG, and total P, Mg and K were measured using the Vitros 350 Chemistry System (Ortho-Clinical Diagnostics, Johnson \& Johnson, New York, United State of America). Fasting serum insulin was determined using an ELISA kit (Diametra Millipore Corporation, Billerica, MA, United State of America).

\section{Statistical analysis}

Experiment 1: data related to triangular tests were analysed by checking the minimum number of correct responses using a binomial table with $P=0.05$ (17). As for the acceptability test, 2-way analysis of variance using the GLM procedure of SAS (version 9.02) was performed as described previously (16). In the statistical model for

\begin{tabular}{|c|c|c|c|}
\hline \multirow[t]{2}{*}{ Mineral } & \multicolumn{3}{|c|}{ Treatment } \\
\hline & WP $(n=3)$ & WP-R (n=3) & WP-F $(n=3)$ \\
\hline Phosphorus (g/kg) & $3.20 \pm 0.01$ & $5.90 \pm 0.00$ & $11.60 \pm 0.00$ \\
\hline Potassium (g/kg) & $3.70 \pm 0.01$ & $5.90 \pm 0.23$ & $12.20 \pm 0.01$ \\
\hline Magnesium (g/kg) & $0.53 \pm 0.01$ & $1.60 \pm 0.04$ & $2.70 \pm 0.26$ \\
\hline
\end{tabular}

$W P=$ white pita bread; $W P-R=$ restored white pita bread; WP-F $=$ fortified white pita bread. Results are expressed as the mean \pm standard deviation (SD). 
acceptability, the response variable was the specific acceptability variable. Factors in the model were the panellist and treatment (WP, WP-R and WP-F). The panellist was included as a random effect and treatment as a fixed effect. Means were separated by Tukey's honestly significant difference test. For all data, significance was established at $\mathrm{P}<0.05$.

Experiment 2: The difference $(\Delta)$ in serum total $\mathrm{P}$, $\mathrm{Mg}, \mathrm{K}, \mathrm{TG}$ and glucose was calculated. This represents the value at each time point minus the value at time 0 . Repeated-measures analysis of variance was used to determine statistical significance with effects of bread type, time, and bread type $\times$ time interaction.

\section{Results}

\section{Experiment 1}

\section{Difference test and hedonic acceptability}

In the triangular difference test, 13 correct answers out of the 24 responses were needed to show a significant difference. However, only 8 and 10 panellists responded correctly for the WP versus WP-R and WP versus WP-F tests, respectively (both $P>0.05$ ). Therefore, the triangular tests did not detect any significant differences between the different types of bread.

The consumer acceptability test (Table 2) found no significant differences for most acceptability attributes (overall acceptability, appearance, colour, odour and flavour; $P>0.05$ ). Texture, however, was significantly more liked than that of the WP-F bread $(P<0.05)$, although no significant difference was detected between WP and WP-R or WP-R and WP-F bread.

\section{Experiment 2}

\section{Participants' characteristics}

Baseline fasting serum levels of glucose, insulin, homeostasis model assessment of insulin resistance (HOMA-IR) (18), TG and total P, K and $\mathrm{Mg}$ were within the normal ranges (Table 3), and these were found to be similar between the different experimental sessions for each type of bread.

\section{Postprandial mineral responses}

Results were expressed as changes from baseline, which were the difference between the macromineral levels at each time point minus their corresponding values at baseline. Postprandial serum levels of the measured mac- rominerals were altered by food ingestion. Serum total $P$ decreased following ingestion of all bread types, although this failed to reach statistical significance. However, the changes in serum total $\mathrm{P}$ were significant between bread types $(P=0.015)$, and serum $P$ in WP-F bread returned to baseline by the end of the session (Figure 1A). Postprandial serum $\mathrm{Mg}$ levels experienced a gradual and significant increase with time $(P=0.027)$, although no significant difference was detected among the different bread types (Figure 1B), despite their varied content of $\mathrm{Mg}$ (Table 1 ). In contrast to $\mathrm{Mg}$, postprandial $\mathrm{K}$ levels decreased with time, although not significantly (Figure $1 C$ ), and were significantly different among bread types $(P=0.001)$.

\section{Postprandial TG and glucose responses}

Results of TG and glucose were also expressed as differences from baseline. The changes in postprandial serum TG (Figure 2A) differed significantly among bread types $(P=0.001)$, and WP-R and WP-F maintained lower levels at all time points. Similarly, changes in postprandial serum glucose (Figure $2 \mathrm{~B}$ ) differed significantly among bread types $(P<0.013)$ and over time $(P<0.001)$. Serum glucose levels peaked at 30-45 minutes after ingestion and the peaks were sooner with the enriched pita breads. Thereafter, the enriched breads exhibited a faster decrease in serum glucose as compared to the WP bread, starting from 45 minutes until the end of the experiment. The magnitude of the decrease seemed to be synergistically related to the mineral content of the bread.

\section{Discussion}

This study was designed to investigate the glycaemic response of macronutrient-enriched pita bread, as well as its sensory properties. Our results showed that the palatability of white pita bread was not affected by the addition of macrominerals, as indicated by the lack of differences in the triangular and acceptability tests. However, a small difference in texture was detected between WP and WP-F but not the triangular test, which is known to be more attentive to differences. Hence, no major differences were observed when the bread was assessed in its entirety. Our findings are in line with other studies, in which addition of $\mathrm{K}, \mathrm{Ca}$ and $\mathrm{Mg}$ salts as replacements for $\mathrm{NaCl}$ did not yield any differences in appearance, texture and taste of brown bread (19). Therefore, it can be concluded that the addition of macrominerals to white wheat flour in an amount comparable to that found in

\begin{tabular}{lccccccc}
\hline Table 2 Hedonic acceptability variables for the different pita bread types & & & & \\
Acceptability variables & $\begin{array}{c}\text { Overall } \\
\text { acceptability }\end{array}$ & Appearance & Colour & Odour & Flavour & Texture \\
& $6.27 \pm 1.33$ & $6.22 \pm 1.17$ & $6.32 \pm 1.08$ & $6.08 \pm 1.34$ & $6.38 \pm 1.54$ & $6.35 \pm 1.72^{\mathrm{a}}$ \\
WP & $6.25 \pm 1.49$ & $6.32 \pm 1.56$ & $6.52 \pm 1.19$ & $6.23 \pm 1.28$ & $5.87 \pm 1.78$ & $5.95 \pm 1.84^{\mathrm{ab}}$ \\
WP-R & $6.07 \pm 1.33$ & $6.28 \pm 1.21$ & $6.40 \pm 1.39$ & $6.12 \pm 1.53$ & $5.85 \pm 1.62$ & $5.42 \pm 1.71^{\mathrm{b}}$ \\
WP-F & 0.601 & 0.861 & 0.542 & 0.795 & 0.066 & 0.004 \\
P value & & & & & &
\end{tabular}

Results are expressed as mean \pm standard deviation $(S D) .{ }^{a, b}$ Means with different superscripts are statistically significant $(P<0.05)$ as analysed by paired $t$-test. WP $=$ white pita bread;

$W P-R=$ restored white pita bread; $W P-F=$ fortified white pita bread. 


\begin{tabular}{lcc}
\hline Table 3 Baseline characteristics of the 11 participants \\
\hline & Mean & SD \\
\hline Age $(\mathrm{yr})$ & 23.7 & 2.4 \\
Weight $(\mathrm{kg})$ & 85.6 & 10.6 \\
Height $(\mathrm{m})$ & 1.80 & 0.04 \\
BMI $\left(\mathrm{kg} / \mathrm{m}^{2}\right)$ & 26.2 & 2.4 \\
Fasting serum glucose $(\mathrm{mg} / \mathrm{dl})$ & 95.0 & 7.8 \\
Fasting serum insulin $(\mu \mathrm{U} / \mathrm{ml})$ & 5.23 & 2.18 \\
HOMA-IR & 1.23 & 0.54 \\
Fasting serum triglycerides $(\mathrm{mg} / \mathrm{dl})$ & 92.5 & 29.4 \\
Fasting serum phosphate $(\mathrm{mg} / \mathrm{dl})$ & 3.76 & 0.53 \\
Fasting serum potassium $(\mathrm{mg} / \mathrm{dl})$ & 4.74 & 0.38 \\
Fasting serum magnesium $(\mathrm{mg} / \mathrm{dl})$ & 1.95 & 0.21 \\
\hline
\end{tabular}

Results are expressed as mean and standard deviation (SD). BMI = body mass index; HOMA-IR = homeostatic model assessment of insulin resistance.

whole wheat flour, and even in double quantities, does not significantly affect acceptability of white pita bread.

The reduction in serum $P$ following ingestion of the different types of bread was in line with other studies $(7,20)$, and this is mediated by insulin, which is known to stimulate peripheral uptake of both glucose and P. Thus, insulin favours glucose phosphorylation (21) in a manner that mimics the action of glucokinase activators (22). The inability of WP and WP-R to normalize serum P (return to baseline at 120 minutes) unlike that of WP-F (7) implies that their P content was not sufficient to meet the needs of intracellular phosphorylation. Moreover, the observed nonsynergistic relation between $\mathrm{Mg}$ content of the bread and changes in postprandial serum $\mathrm{Mg}$ is likely to result from the ability of $\mathrm{P}$ to potentiate insulin sensitivity $(7,23,24)$, which is known to stimulate $\mathrm{Mg}$ clearance (20). Furthermore, improvement in insulin sensitivity may have also been attributed to the nonsynergistic relation between $\mathrm{K}$ content of bread and changes in postprandial serum K levels. Likewise, $\mathrm{Mg}(25,26)$ and $\mathrm{K}$ (27) are reported to improve glucose clearance and insulin sensitivity. The ability of macrominerals ( $\mathrm{P}, \mathrm{Mg}$ and $\mathrm{K}$ ) to enhance their own intracellular uptake may help to explain the reported inverse association between $\mathrm{P}$ intake and blood pressure (28). This further implies that postprandial levels of these macrominerals depend on a balance between their availability in the circulation and their capacity for intracellular uptake and storage, and this implies that their circulating level is not a good indicator of their bodily status.

At the glycaemic level, the inverse association between the macromineral content of bread and postprandial glucose level, especially from time 60 minutes (7), may have been the outcome of an improvement in glucose clearance due to the capacity of the added minerals to improve glucose phosphorylation and insulin sensitivity. Furthermore, this capacity may have also contributed to the observed reduction in serum TG after ingestion of enriched bread (WP-R and WP-F). Our findings suggest that postprandial glucose and TG levels, especially from 60 minutes, are dependent on exogenous factors including $\mathrm{P}, \mathrm{Mg}$ and $\mathrm{K}$. In support, $\mathrm{P}$ status was reported to correlate with a favourable lipid profile, including increased high-density lipoprotein and decreased serum TG levels $(10,12)$. In agreement, we have recently found that the addition of $\mathrm{P}$ to a high-fat meal was able to alter postprandial lipidaemia by increasing apolipoprotein B48 and decreasing apolipoprotein B10o (29). Besides, Mg supplementation also improves postprandial lipidaemic response in healthy individuals (30).

Worldwide, daily consumption of wheat and wheat products, mainly in the form of bread and pasta, is about $180 \mathrm{~g}$ per capita and this contributes to about $20 \%$ of total energy intake (31). Even with a consumption of $500 \mathrm{~g} /$ day of WP-R, which is considered an excessive amount compared to the reported daily consumption of about 150 $\mathrm{g}$ per day (32) and is equivalent to around $4604.6 \mathrm{~kJ}(1100$ kcal), the upper limit for both $\mathrm{P}$ and $\mathrm{Mg}$ would not be reached. The high palatability of white pita bread makes it popular and a major contributor to overall glycaemic load, which increases the risk of development of diabetes, abnormal lipid profile and obesity $(33,34)$.

Nonetheless, the health benefits of whole wheat cereal products are reported not to be related to their fibre content (35); therefore, our findings may partially explain the benefits of whole wheat products that are known to have high content of macrominerals, specifically $\mathrm{P}, \mathrm{Mg}$ and K. Even though the beneficial effects of whole grains have been widely publicized, the adoption of diets rich in whole grains is still facing resistance, probably due to their low palatability.

The major limitation of this study was that postprandial insulin and other appetite hormone levels were not measured. In addition, the contribution of each mineral to the observed changes was not clear. Further studies are required to determine the postprandial response of prediabetic and diabetic patients, as well as the long-term impact of macronutrient enrichment on diabetes and different components of the metabolic syndrome.

\section{Conclusion}

White wheat flour enrichment with macrominerals ( $P$, $\mathrm{Mg}$ and $\mathrm{K}$ ) did not affect the palatability of white pita bread, while postprandial glucose and TG levels were reduced. Furthermore, this supports the benefit of increasing the consumption of whole grain wheat, since it retains most of its mineral content. This study successfully identified the beneficial role of minerals in improving the glycaemic response of a simple carbohydrate product, white pita bread. The data may prove useful to ameliorate the detrimental potential effect of simple carbohydrates.

Funding: The work was supported by the Farouk Jaber Innovative Biomedical Research Award from the Faculty of Medicine, American University of Beirut. Award number 100410. The funder had no role in the design, analysis or writing of this article.

Competing interests: None declared. 
Figure 1 Postprandial changes in phosphorus (A), magnesium (B) and potassium (C) following the ingestion of different pita breads. All values are presented as mean and standard error of the mean. The difference reflects changes between the variable at each time point and the same variable at baseline $(t=0)$
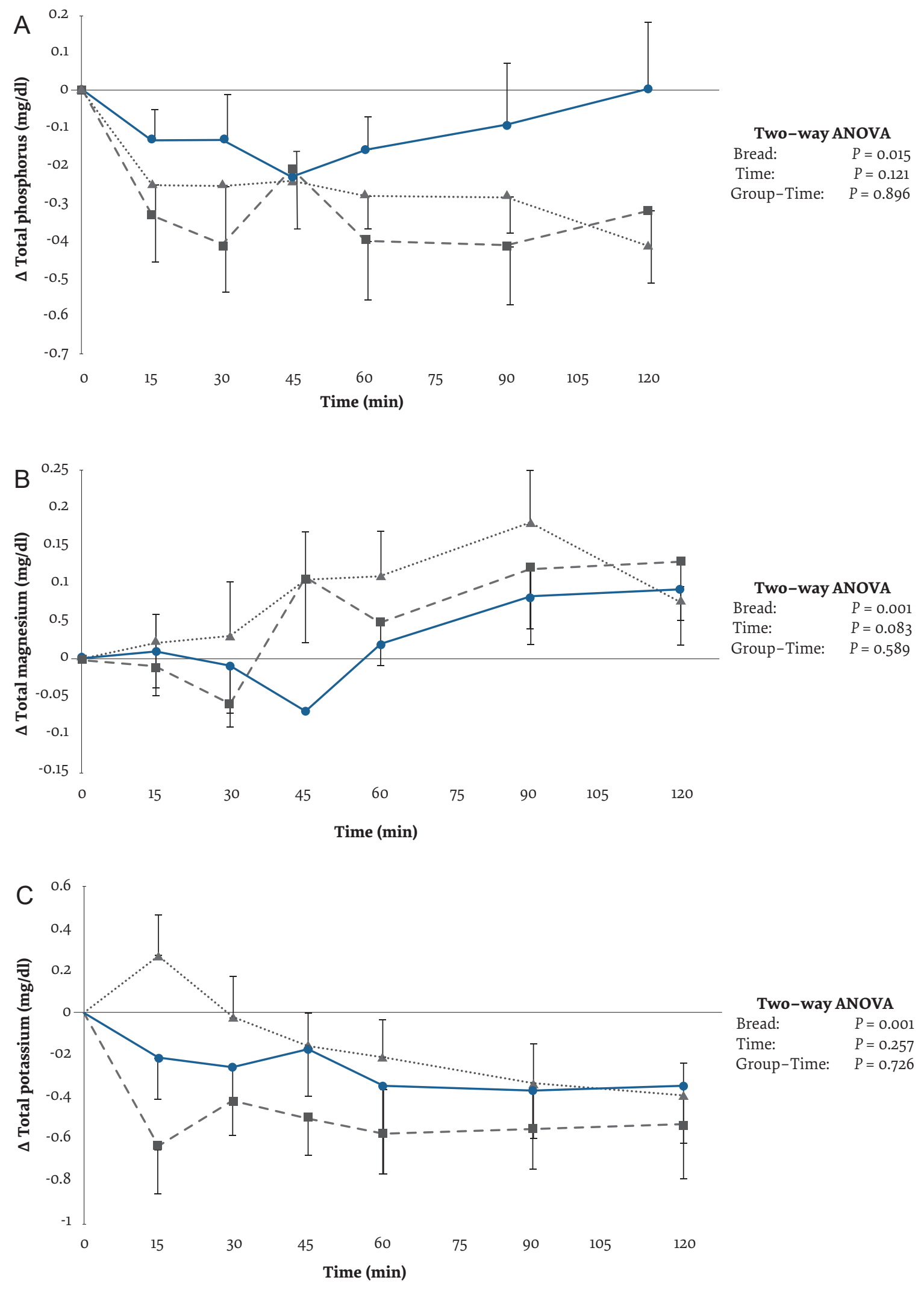

................ white pita bread $\quad--\square-$ white pita bread-restored $\quad \longrightarrow$ white pita bread-fortified 
Figure 2 Postprandial changes in triglycerides (A) and glucose (B) following the ingestion of different pita breads. All values are presented as mean and standard error of the mean. The difference reflects changes between the variable at each time point and the same variable at baseline $(\mathrm{t}=\mathrm{o})$
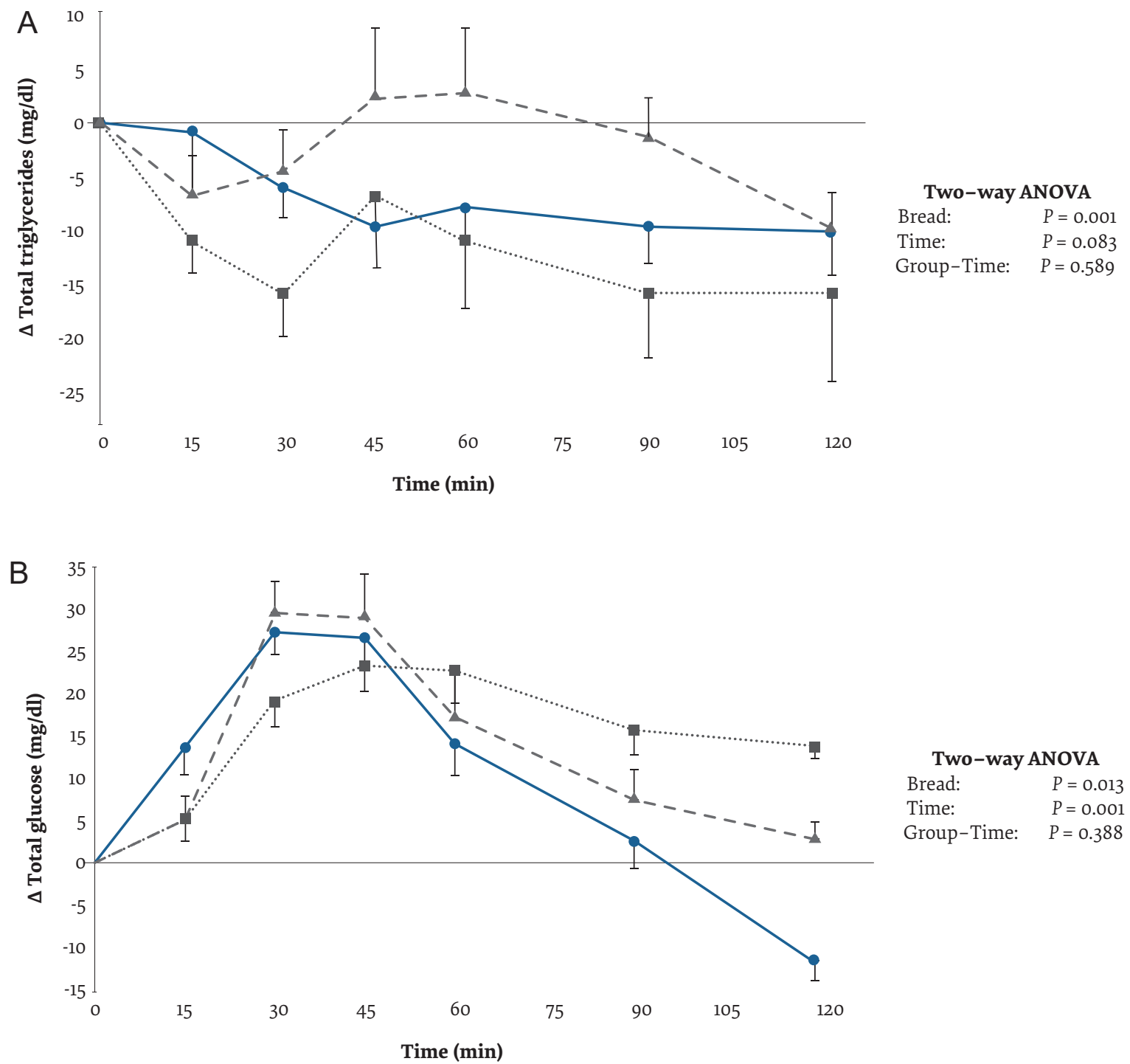

…........... white pita bread $\quad--\square_{-}$- white pita bread-restored $\quad \longrightarrow$ white pita bread-fortified

\section{Enrichissement en macro-minéraux du pain blanc et réduction de la glycémie postprandiale sans altération des propriétés sensorielles : étude croisée \\ Résumé}

Contexte : On sait que le métabolisme des glucides raffinés, qui sont associés à des effets nocifs sur la santé, est affecté par les macro-minéraux, notamment le phosphore, le magnésium et le potassium.

Objectifs : Évaluer l'impact de l'ajout de ces macro-minéraux à la farine sur les propriétés sensorielles du pain pita blanc et sur la glycémie postprandiale d'individus en bonne santé.

Méthodes : La présente étude a été menée à l'Université américaine de Beyrouth (entre février et octobre 2014). De la farine nature, de blé germé et enrichie en macro-minéraux a été utilisée pour préparer 3 types de pain : du pain pita blanc, du pain pita blanc à la farine de blé germé (degrés de prémouture) et du pain pita blanc enrichi (degrés de prémouture multipliés par deux). Les caractéristiques sensorielles du pain ont été évaluées et la glycémie postprandiale a été déterminée à l'aide d'un modèle croisé en simple aveugle, dans lequel les participants ont consommé un des trois différents types de pain pita dans un ordre aléatoire. 
Résultats : Aucune différence significative $(p>0,05)$ entre les différents types de pain n'a été détectée à l'aide de la méthode triangulaire et des tests d'acceptabilité, à l'exception de la texture $(p<0,05)$. Lenrichissement en macro-minéraux du pain (à la farine de blé germé et à la farine enrichie) a permis de réduire significativement les taux de glucose $(p=0,013)$ et de triglycérides $(p=0,001)$ postprandiaux.

Conclusions : Lenrichissement en macro-minéraux des glucides raffinés peut jouer un rôle prometteur dans la diminution du glucose et des triglycérides postprandiaux, et ainsi diminuer leurs conséquences néfastes sur la santé.

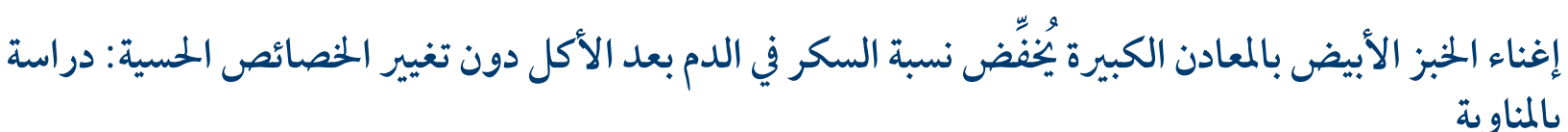$$
\text { رانيا الخوري، نور الصُّلح، عمار العُبي، عحاد الطفيلي، ساني حليس، عمر عبيد }
$$

الخلفية: من المعروف أن المعادن الكبيرة بما فيها الفوسفور والمجنيسيو و البوتاسيوم تؤثّر على التمثيل الغذائي للكربو هيدرات المُنقّاة التي ينجم عنها آثار صحية ضارة.

الأهداف: هدفت هذه الدراسة إلى تقييم تأثير إضافة المعادن الكبيرة إلى الدقيق على الخصائص الحسية للخبز العربي الأبيض وسكر الدم بعد الأكل

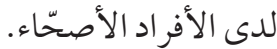

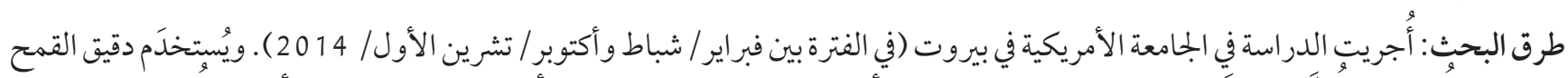

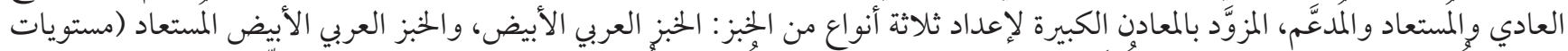

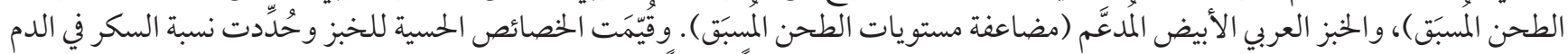

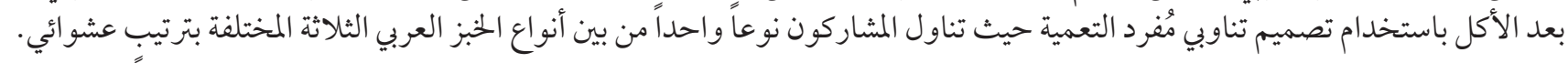

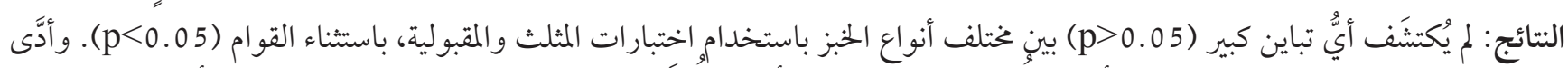

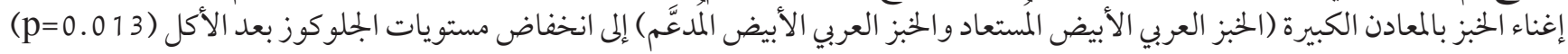
وثلاثي جليسيريد الدم (p=0 0.001$)$

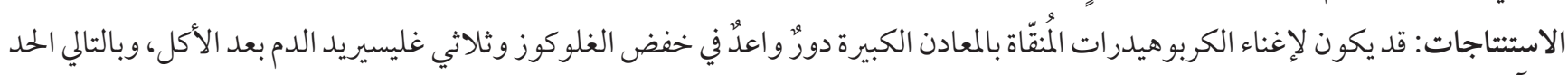

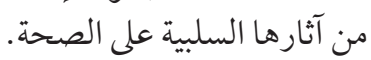

\section{References}

1. Popkin BM, Gordon-Larsen P. The nutrition transition: worldwide obesity dynamics and their determinants. Int J Obes. 2004 Nov;28(Suppl 3):S2-S9. http://dx.doi.org/10.1038/sj.ijo.0802804 PMID:15543214

2. 2015-2020 Dietary guidelines for Americans, 8th edition. Washington DC: U.S. Department of Health and Human Services and U.S. Department of Agriculture; 2015. (http://health.gov/dietaryguidelines/2015/guidelines/, accessed 20 December 2019).

3. FoodData Central [website]. Washington DC: U.S. Department of Agriculture, Agricultural Research Service; 2019 (https://fdc.nal. usda.gov, accessed 20 December 2019).

4. Larsson SC, Wolk A. Magnesium intake and risk of type 2 diabetes: a meta $\square$ analysis. J Intern Med. 2007 Aug;262(2):208-14. http:// dx.doi.org/10.1111/j.1365-2796.2007.01840.x PMID:17645588

5. He FJ, MacGregor GA. Beneficial effects of potassium on human health. Physiol Plant. 2008 Aug;133(4):725-35. http://dx.doi. org/10.1111/j.1399-3054.2007.01033.x PMID:18724413

6. Bouché C, Serdy S, Kahn CR, Goldfine AB. The cellular fate of glucose and its relevance in type 2 diabetes. Endocr Rev. 2004 Oct;25(5):807-30. http://dx.doi.org/10.1210/er.2003-0026 PMID:15466941

7. Khattab M, Abi-Rashed C, Ghattas H, Hlais S, Obeid O. Phosphorus ingestion improves oral glucose tolerance in healthy male subjects: a crossover experiment. Nutr J. 2015 Oct 29;14:1. http://dx.doi.org/10.1186/s12937-015-0101-5 PMID:26514124

8. Suarez A, Pulido N, Casla A, Casanova B, Arrieta FJ, Rovira A. Impaired tyrosine-kinase activity of muscle insulin receptors from hypomagnesaemic rats. Diabetologia. 1995 Nov;38(11):1262-70. http://dx.doi.org/10.1007/bfoo401757 PMID:8582534

9. Barbagallo M, Dominguez LJ, Galioto A, Ferlisi A, Cani C, Malfa L, et al. Role of magnesium in insulin action, diabetes and cardio-metabolic syndrome X. Mol Aspects Med. 2003 Feb-Jun;24(1-3):39-52. http://dx.doi.org/10.1016/s0098-2997(02)00090-0 PMID:12537988 
10. Kalaitzidis R, Tsimihodimos V, Bairaktari E, Siamopoulos KC, Elisaf M. Disturbances of phosphate metabolism: another feature of metabolic syndrome. Am J Kidney Dis. 2005 May;45(5):851-8. http://dx.doi.org/10.1053/j.ajkd.2005.01.005 PMID:15861350

11. Obeid O, Hachem D, Ayoub J. Refeeding and metabolic syndromes: two sides of the same coin. Nutr Diabetes. 2014 Jun 30;4:e120. http://dx.doi.org/10.1038/nutd.2014.21 PMID:24979149

12. Grundy SM. Hypertriglyceridemia, insulin resistance, and the metabolic syndrome. Am J Cardiol. 1999 May 13;83(9B):25F-9F. http://dx.doi.org/10.1016/s0002-9149(99)00211-8 PMID:10357572

13. Institute of Medicine. Dietary reference intakes for calcium, phosphorus, magnesium, vitamin d, and fluoride. Washington, DC: National Academies Press; 1997.

14. Toufeili I, Ismail B, Shadarevian S, Baalbaki R, Khatkar BS, Bell AE, et al. The role of gluten proteins in the baking of Arabic bread. J Cereal Sci. 1999 Nov;30(3):255-65. https://doi.org/10.1006/jcrs.1999.0286

15. Methods for the determination of metals in environmental samples. United States Environmental Protection Agency; 1991.

16. Lteif L, Olabi A, Baghdadi OK, Toufeili I. The characterization of the physicochemical and sensory properties of full-fat, reduced-fat, and low-fat ovine and bovine Halloumi. J Dairy Sci. 2009 Sep;92(9):4135-45. http://dx.doi.org/10.3168/jds.2009-2070 PMID:19700674

17. Lawless HT, Heymann H. Acceptance testing. In: Sensory evaluation of food: principles and practices, 2nd edition. New York: Springer Science \& Business Media; 2010:325-36.

18. Matthews DR, Hosker JP, Rudenski AS, Naylor BA, Treacher DF, Turner RC. Homeostasis model assessment: insulin resistance and $\beta$-cell function from fasting plasma glucose and insulin concentrations in man. Diabetologia. 1985 Jul;28(7):412-9. http:// dx.doi.org/10.1007/bfoo280883 PMID:3899825

19. Charlton KE, Macgregor E, Vorster NH, Levitt NS, Steyn K. Partial replacement of NaCl can be achieved with potassium, magnesium and calcium salts in brown bread. Int J Food Sci Nutr. 2007 Nov;58(7):508-21. http://dx.doi.org/10.1080/09637480701331148 PMID:17852502

20. Rosenbloom AL. Serum calcium and magnesium decline during oral glucose tolerance testing in children and adolescents with preclinical diabetes mellitus less than in normals. Metabolism. 1977 Sep;26(9):1033-9. http://dx.doi.org/10.1016/00260495(77)90021-x PMID:895534

21. Amanzadeh J, Reilly RF. Hypophosphatemia: an evidence-based approach to its clinical consequences and management. Nat Clin Pract Nephrol. 2006 Mar;2(3):136-48. http://dx.doi.org/10.1038/ncpnepho124 PMID:16932412

22. Meininger GE, Scott R, Alba M, Shentu Y, Luo E, Amin H, et al. Effects of MK-0941, a novel glucokinase activator, on glycemic control in insulin-treated patients with type 2 diabetes. Diabetes Care. 2011 Dec;34(12):2560-6. http://dx.doi.org/10.2337/dc11-1200 PMID:21994424

23. Nowicki MI, Fliser DA, Fode PE, Ritz EB. Changes in plasma phosphate levels influence insulin sensitivity under euglycemic conditions. J Clin Endocrinol Metab. 1996 Jan;81(1):156-9. http://dx.doi.org/10.1210/jcem.81.1.8550745 PMID:8550745

24. Paolisso G, Scheen A, d'Onofrio F, Lefebvre P. Magnesium and glucose homeostasis. Diabetologia. 1990 Sep;33(9):511-4. http:// dx.doi.org/10.1007/bfo0404136 PMID:2253826

25. Swaminathan R. Magnesium metabolism and its disorders. Clin Biochem Rev. 2003 May;24(2):47. PMID:18568054

26. Yajnik CS, Smith RF, Hockaday TD, Ward NI. Fasting plasma magnesium concentrations and glucose disposal in diabetes. Br Med J (Clin Res Ed). 1984 Apr 7;288(6243):1032-4. http://dx.doi.org/10.1136/bmj.288.6423.1032 PMID:6423182

27. Zillich AJ, Garg J, Basu S, Bakris GL, Carter BL. Thiazide diuretics, potassium, and the development of diabetes a quantitative review. Hypertension. 2006 Aug;48(2):219-24. http://dx.doi.org/10.1161/01.HYP.0000231552.10054.aa PMID:16801488

28. Nguyen TQ, Maalouf NM, Sakhaee K, Moe OW. Comparison of insulin action on glucose versus potassium uptake in humans. Clin J Am Soc Nephrol. 2011 Jul;6(7):1533-9. http://dx.doi.org/10.2215/CJN.00750111 PMID:21734082

29. Hazim J, Hlais S, Ghattas H, Shatila D, Bassil M, Obeid O. Phosphorus supplement alters postprandial lipemia in healthy male subjects: a pilot cross-over trial. Lipids Health Dis. 2014 Jul 8;13:1. http://dx.doi.org/10.1186/1476-511X-13-109 PMID:25002136

30. Kishimoto Y, Tani M, Uto-Kondo H, Saita E, Iizuka M, Sone H, Yokota K, et al. Effects of magnesium on postprandial serum lipid responses in healthy human subjects. Br J Nutr. 2010 Feb;103(4):469-72. http://dx.doi.org/10.1017/Sooo7114509992716 PMID:19941679

31. FAOSTAT. Food and agriculture data [website]. Food and Agriculture Organization of the United Nations (http://faostat3.fao.org/ download/FB/FBS/E, accessed 20 December 2019).

32. Nasreddine L, Hwalla N, Sibai A, Hamzé M, Parent-Massin D. Food consumption patterns in an adult urban population in Beirut, Lebanon. Public Health Nutr. 2006 Apr;9(2):194-203. http://dx.doi.org/10.1079/phn2005855 PMID:16571173

33. Chiu CJ, Liu S, Willett WC, Wolever TM, Brand-Miller JC, Barclay AW, et al. Informing food choices and health outcomes by use of the dietary glycemic index. Nutr Rev. 2011 Apr;69(4):231-42. http://dx.doi.org/10.1111/j.1753-4887.2011.00382.x PMID:21457267

34. Liu S, Manson JE, Stampfer MJ, Hu FB, Giovannucci E, Colditz GA, et al. A prospective study of whole-grain intake and risk of type 2 diabetes mellitus in US women. Am J Public Health. 2000 Sep;90(9):1409. http://dx.doi.org/10.2105/ajph.90.9.1409 PMID:10983198

35. Pereira MA, Jacobs DR, Pins JJ, Raatz SK, Gross MD, Slavin JL, et al. Effect of whole grains on insulin sensitivity in overweight hyperinsulinemic adults. Am J Clin Nutr. 2002 May;75(5):848-55. http://dx.doi.org/10.1093/ajcn/75.5.848 PMID:11976158 